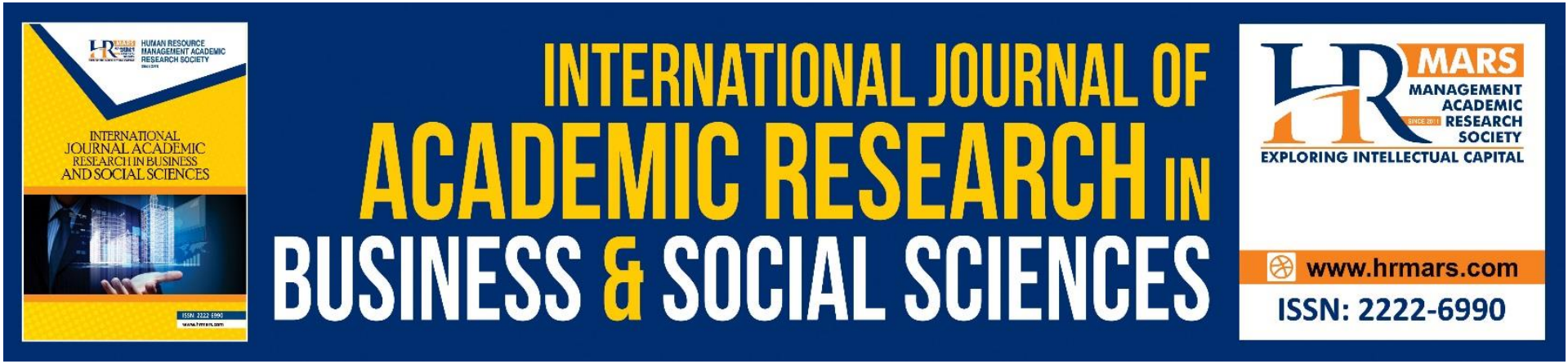

\title{
Assessing Motivations towards Green Product Purchase Behaviour among Young Malaysian: Empirical Evidence
}

Wan Kalthom Yahya, Norhusniyati Husin, Najihah Abdul Rahim, Nik Rozila Nik Mohd Masdek, Siti Rohana Daud

To Link this Article: http://dx.doi.org/10.6007/IJARBSS/v11-i11/11182

DOI:10.6007/IJARBSS/v11-i11/11182

Received: 05 September 2021, Revised: 28 September 2021, Accepted: 20 October 2021

Published Online: 06 November 2021

In-Text Citation: (Yahya et al., 2021)

To Cite this Article: Yahya, W. K., Husin, N., Rahim, N. A., Masdek, N. R. N. M., \& Daud, S. R. (2021). Assessing Motivations towards Green Product Purchase Behaviour among Young Malaysian: Empirical Evidence. International Journal of Academic Research in Business and Social Sciences, 11(11), 222 - 237.

Copyright: (c) 2021 The Author(s)

Published by Human Resource Management Academic Research Society (www.hrmars.com)

This article is published under the Creative Commons Attribution (CC BY 4.0) license. Anyone may reproduce, distribute, translate and create derivative works of this article (for both commercial and non-commercial purposes), subject to full attribution to the original publication and authors. The full terms of this license may be seen at: http://creativecommons.org/licences/by/4.0/legalcode

Vol. 11, No. 11, 2021, Pg. $222-237$

Full Terms \& Conditions of access and use can be found at http://hrmars.com/index.php/pages/detail/publication-ethics 


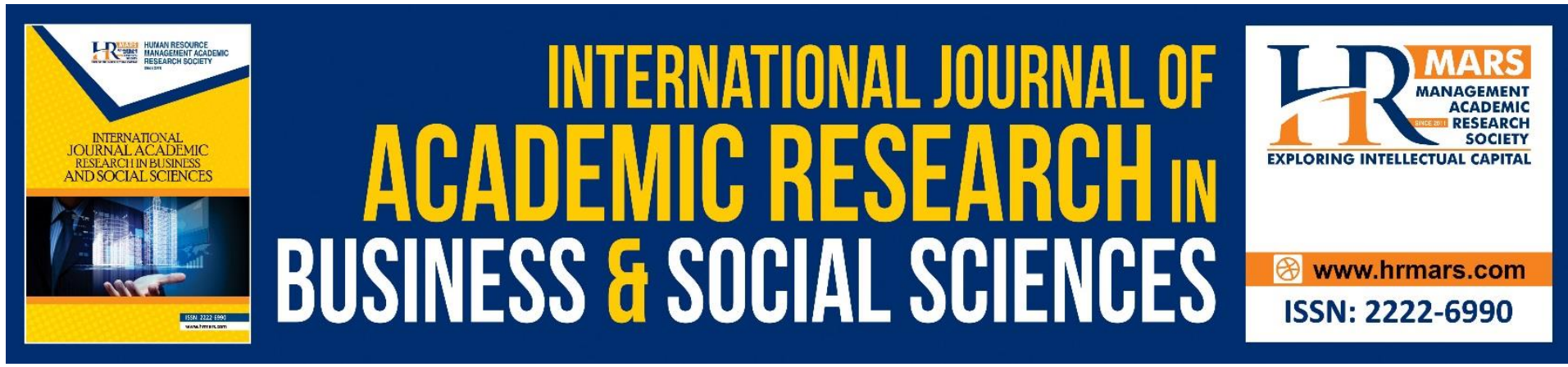

\title{
Assessing Motivations towards Green Product Purchase Behaviour among Young Malaysian: Empirical Evidence
}

\author{
Wan Kalthom Yahya1, Norhusniyati Husin², Najihah Abdul \\ Rahim $^{3}$, Nik Rozila Nik Mohd Masdek ${ }^{4}$, Siti Rohana Daud ${ }^{5}$ \\ 1,2,3,5 Universiti Teknologi MARA, Melaka, Kampus Alor Gajah, Malaysia, ${ }^{4}$ Universiti Teknologi \\ MARA, Selangor, Kampus Puncak Alam, Malaysia \\ Email: wkalthom@uitm.edu.my
}

\begin{abstract}
Numerous studies on environmentally conscious behaviour have looked at age as primary concern. According to some studies, younger generations are more environmentally conscious. The most frequently used argument is that those who grew up during the social movements over environmental consciousness are more likely to be sympathetic to the issues. Understanding how young people make green product purchasing decisions has a significant impact on green marketing strategies. A better understanding of what motivates these young consumers to buy green products may also help reduce the impact of irresponsible consumption in the future. Their consumption patterns are distinct from "traditional" consumption. Their typical consumption pattern has been characterized by open-mindedness, hedonism, and visibility. To a certain extent, their consumption habits reflect a form of self-expression, personal identity formation, creativity, or even art. Thus, the purpose of this study is to determine whether key factors such as environmental consciousness, environmental attitude, eco labelling, and green advertising influenced young Malaysians' green purchase behaviour. A self-administered questionnaire was distributed, which garnered 431 responses across the country. The confirmatory factor analysis (CFA) was used to evaluate the associated route coefficients between the different variables, and structural equation modelling was used for hypothesis testing. Overall, the results showed that green advertising was the most important predictor of green purchase behaviour among younger generations. The study's findings will assist green marketers in improving their strategies of promoting green products to younger generations.
\end{abstract}

Keywords: Young Consumers, Environmental Consciousness, Environmental Attitude, Eco Labelling, Green Purchase Behaviour

\section{Introduction}

Increased environmental awareness since the 1970s has made positive changes in consumer behaviour towards environmental products (Alwitt and Pitts, 1996). Mindfulness and consciousness of the environment have created a 'sustainable development' social movement that emphasizes urgent situations to promote sustainable consumption in an 
effort to reduce its impact on the environment and society. A basic understanding of environmental and social problems will motivate consumers to adopt sustainable consumption practices. A broader understanding of the results of irresponsible consumption may be more effective in switching to green purchasing products and at the same time adopting green consumption behaviours. Therefore, the latest information dissemination method to ensure that consumers benefit from green products is important in ensuring that they continue to use and purchase green products.

Such information can be displayed through special labels and media that will provide details on the nature of sustainable products. Thus, sustainable development aggressively drives the growth of eco-innovation and green consumption. In fact, over the past two decades, the world has witnessed a dramatic increase in environmental consciousness. This leads to a strong influence on young generation green behaviour, by expanding green products in the market. In other words, consumer green buying behaviour benefits green marketers. Because globalization trends have forced organisations to focus on the public interest to compete effectively, thus, being green has become a trend among marketers to create their own eco-friendly product line.

It is a common understanding that the general consumption has been a result of changes in the level of affluence and lifestyles of various generations. Malaysia in particular is divided into five generations. The first-generation cohort is still in their late adolescence and early adulthood, which is noteworthy. They were apparently born after 1990 and have a strong interest in communication technologies (Ting et al., 2018). Therefore, in this study our focus is on those who are born on and after 1990 as to see the motivations behind their green purchase. Consumers, especially the young ones, are more diverse and astute than ever before, and as a result, they demand products (both tangible and intangible) that align with their values and lifestyles (Meredith et al., 2002). Malaysian generations are likewise. Nonetheless, Malaysian changing consumer lifestyles, excessive consumption and reckless spending (Ong et al., 2021) have become more apparent. This may result in a huge number of material and household waste (Moh and Abd Manaf, 2014). Previous studies have confirmed excessive consumption in this country is related to the consumption-oriented lifestyles. Chai, Lung and Ramly (2009) raised concern if the youngsters today are inclined to accept more unethical behaviours and be less tolerant. It was discovered that failure to resolve environmental problems or to maintain a healthy environment is a result of an overemphasis on technical, socioeconomic, and political factors and an insufficient emphasis on the environment's non-economic value (Tikka et al., 2000). Fundamentally, environmental problems are caused by excessive consumption behaviour and human activity (Zhai et al., 2020).

The younger generation is important as they represent future customers in the future community. They are characterized as materialistic, tend to be more flexible than previous generations and they will spend time looking for information before making a real purchase. In addition, the young generation is more receptive to innovative ideas, they socially interact and are more open-minded about environmental issues compared to previous generations (Hume, 2010). These features make them the strongest and most promising group of customers. Goh and Wahid (2015) do agree that the younger generation of Malaysia is a group that will penetrate the green market in the future. Therefore, it is very important for marketers to educate young people by developing and understanding their green purchase behaviour and the factors that influence it. 
To overcome the problem, the Malaysian government has taken a lot of initiatives to engage customers to a more sustainable oriented consumption behavior. Among those initiatives include recycling campaigns, solid waste management programs and numerous campaigns. However, if the awareness does not come from these young generations of consumers, all the effort will be meaningless. As mentioned by Longhurst (2007) the responsibility of developing a sustainable practice is no longer in the hands of a specific segment of the economy. Rather, it is becoming a responsibility of a key stakeholder group for example young consumers (Hume, 2010). This supports Mansaray and Abijoye's (1998) earlier assertion that the quality of the environment is contingent on the people's level of attitude, knowledge, values, and practices. However, to profile a green consumer segment, marketers must first identify young pro-environmental behaviour before launching an environmentally friendly product. In profiling greener consumers in accordance with their pro-environmental purchasing behaviour, elements such as environmental awareness, environmental attitudes, and green marketing tools are eco-labelling, and green advertising seems to be more appropriate to characterize the purchasing results of young consumer green products. These variables can be attributed to socio-demographics in understanding the greater influence between the decision to purchase green products and the purchasing habits of this green market segment. Hence, this paper is intended to gain an empirical insight into the motivation towards green purchase behaviour of young Malaysians by analysing the influence on environmental consciousness, eco labelling, environmental attitude, and advertising on green consumption spending.

\section{Literature Review \\ Green Purchase Behaviours}

The United Nations Environment Program defines sustainable consumption as "the use of services and related products that meet basic needs and improve quality of life while minimising the use of natural resources and toxic materials, as well as waste and pollution emissions throughout the product's life cycle in order to avoid jeopardising future generations' needs." The concept alludes to the necessity of adhering to global resource sustainability guidelines.

In terms of purchasing behaviour or consumption of food and services, consumers are mostly affected by their values. Values are considered "the consumer's overall assessment of the utility of a product based on perceptions of what is received and what is given" (Kim and Chung, 2011). Interestingly, over the last few decades, there has been a noticeable increase in pro-environmental attitudes, consumer knowledge, and behaviours (Laroche, Bergeron and Barbaro-Forleo, 2001).

As such, a study conducted by Topic and Mitchell (2019), discovered there is a satisfaction achieved by consumers from purchasing products with various sustainable features. Businesses adapt in numerous imaginative and significant ways to these contemporary circumstances in order to remain competitive, and begin to integrate these newly emerging concerns into their administrative and marketing decision-making processes (Rivera-Camino, 2007).Customer green purchase behaviour is constantly evaluated on a regular basis in terms of user objectives and eagerness to purchase green products, and then the deliberate purchase behaviour is typically changed to green purchase behaviour, which has an effect on customer behaviour when it comes to purchasing such environmentally friendly items (Joshi and Rahman, 2015). In order to characterize the green consumer purchase behaviour, the Theory of Planned Behavior (TPB) was used in the study. This is 
similar to the study by Hsu et al (2017), which adopted the same theory. Additionally, altered behavioural measures have been applied to a variety of environmentally friendly products, including those manufactured in Asia and India (Hsu et al., 2017), green goods (Zhou et al., 2014), and skincare products (Hsu et al., 2017). Another study by Dilotsotlhe (2021) also suggested that relative benefit, similarity, and perception all have a strong influence on South African millennials' attitudes toward green purchasing behaviour.

\section{Environmental Consciousness}

Engaging in a general purchase behaviour is motivated by an assessment of the benefits and costs that are unique to the consumer who is performing the behaviour (Kim and Choi, 2005). In contrast, according to them, environmentally conscious behaviour is unlikely to deliver instant personal gain or gratification, but rather the future oriented outcome (for instance cleaner environment) that will benefit the society as a whole (McCarthy and Shrum, 2001). Environmental conscious consumers are similar to the green behaviour as defined by Peattie and Charter (2003) as "the holistic management process responsible for identifying, anticipating and satisfying the needs of customers and society, in a profitable and sustainable way". The growing concern for the environment among society's citizens has resulted in consumers demonstrating this concern or awareness through their purchasing decisions (including a preference for environmentally friendly, "green" products over others). This has resulted in a constant increase in the number of pro-environmental consumers, as well as an increase in the population targeted by the pro-environmental population (Menon and Menon, 1997).

Moreover, environmental consciousness on materialism value among young society indicates positive and beneficial impact from the study that is being conducted (Ergen, Baykan \& Turan, 2015). Furthermore, Lin and Niu (2018) also discover reputable and good results on environmental consciousness, environmental knowledge, social norms, and well-being based on environmental attitudes and individual attitudes. Based on Law et al (2017), the study also stated awareness on environmental consciousness was one of the factors that positively connected to environmental attitudes in which society tends to give full commitment for their green spending in order to support and protect the environment. However, the research by Awad (2011) surprised many. According to the author, regardless of the amount of effort and energy spent educating consumers about responsible consumption, marketers recognised that consumers' environmental concerns did not translate into purchasing behaviour (Awad, 2011).

Thus, that has led to the following hypothesis:

$\mathrm{H} 1$ : The green product purchase decisions among youngsters is significantly affected by their environmental consciousness

\section{Eco Labelling}

The manner in which products communicate their sustainability messages via packaging continues to be an intriguing topic in academia, particularly those that concern visual layout and various types of labelling, most notably the visual ecology of packaging (Peschel et al., 2019).The significance of this study is that it will be able to determine what would happen if retailers, brand owners, and possibly even policymakers could alter the visual ecology of packaging by increasing the visibility of sustainability labelling. These small changes can persuade consumers to pay more attention to sustainability, particularly if they already exhibit similar behaviours (Topic and Mitchell, 2019). There are consumers that are really 
concerned about green products that are being marketed in Malaysia. Basically, these groups of consumers will look at the label of products or services that are eco-friendly. To them, eco labelling is very important in purchasing environmentally friendly products.

Surprisingly, Malaysia was the pioneer country in Asia that developed a multidimensional measure in measuring a consumer perception of eco labelling in promoting eco-friendly consumption (Taufique et al., 2019) and Indonesia has followed suit in examining the factors that influence the purchase intentions of young consumers (Auliandri et al., 2018). According to Wei et al (2018), claims about food manufacturing, employee welfare, and ecofriendly packaging all have a positive effect on consumers' intention to purchase.

According to Global Eco labelling Network (GEN) 2020, eco labelling is a voluntary method of environmental performance certification and labelling that is practiced around the world. Eco labelling identifies products or services that have been determined to be more environmentally friendly in aggregate, within a given product or service category. In Malaysia, the Minister of Energy, Green Technology and Water is indeed supporting the world in providing eco-friendly products and services. One of the encouragements that was done by the ministry for eco labelling and certification was appointing SIRIM to develop a SIRIM eco labelling scheme (KeTTHA/SIRIM - 001, 2015). These need to be done in fulfilling the needs of Malaysian industry to cater the requests for domestic and foreign purchasers. Similarly, it emphasizes the critical role of environmental information in changing consumer behaviour by emphasizing the responsibility of green marketing to cultivate awareness.

By having the eco labelling under SIRIM scheme, it can boost the product acceptance in "green market" internationally and also the product or services can be sold at premium price (SIRIM, 2019, 2018). Gallaste-gui (2002) concluded that eco labelling and certification play a critical (precarious) role in raising production standards and assisting consumers in classifying sustainable products. In 1978, the German Federal Government established the world's first environmental certification and eco labelling system, Der Blaue Engel (The Blue Angel) (Umweltbundesamt, 2018).

Certification and eco labelling are being actively used by British women from higher economic groups in order to purchase products for their household every week.Despite the obvious benefits of environmental certification and eco labelling, only a small percentage of the general population actively shops for eco-labelled products on a weekly basis (Ostfeld, 2019). This demonstrates that certification and eco labelling are important factors in determining a consumer's motivation to purchase green products. This has led to the following hypothesis:

$\mathrm{H} 2$ : The green product purchase behaviour among youngsters is significantly affected by eco labelling

\section{Environmental Attitude}

The term "environmental attitude" refers to an individual's subjective assessment of the importance of environmental protection. It is a psychological term that refers to an individual's cognitive assessment of the importance of environmental protection (Lee, 2008). It is parallel to Stern (2000) which explains that EA as a cognitive judgment is intimately linked to environmental protection, it also will reflect individual ecological worldview of human interaction with nature or the environment. Milfont and Duckitt (2010) also defined EA as the central construct in environmental psychology, defining it as a psychological tendency expressed through favourable or disfavorable evaluative responses to the natural environment. Environmental Attitude cannot be observed directly because it is a latent 
construct and can only conclude it from apparent responses (Himmelfarb, 1993). To better understand environmental attitude, research conducted by Gupta and Ogden (2009), has found that individual characteristics such as trust, in-group identity, expectation of others' cooperation and perceived efficacy were useful in identifying environmental attitude among buyers. Another study by Schultz et al (2004), they regard environmental assessment as the collection of a person's beliefs, affect, and behavioural intentions regarding environmental activities or issues. Environmental attitude includes personal value that makes cognitive judgement as the basis by providing evaluative responses to matters or issues related to environmental protection. It is influenced by the trust, belief, and behavioral intention of the individual and perhaps the group. This attitude will be translated into the highly conscious behavior of environmental protection including purchase behavior. It is supported by the finding of Maniatis (2016) which states that consumers' purchasing decisions of environmentally friendly products are frequently influenced by their underlying attitude, values perception, and behavioural intentions toward environmentally friendly products. Rahmayanti et al (2020) also found students are demonstrated by disposing and handling waste according to their place. They are people who have a good environmental attitude. Additionally, it is important to create a tool that can support them to be able to dispose of trash smartly called smart trash. This is a tool that can also be employed as a channel for environmental learning for students at different education levels. Indirectly, this practice is extended to other things such as purchasing behavior. However, in a study conducted by Connell (2010), it was discovered that consumers who have a positive attitude toward environmentally friendly products and who make purchasing decisions may be restricted by other factors such as a lack of choice, the cost of the products, and conflicting information. This is reported by other studies by Eze and Ndubisi (2013), which mentioned that there is a significant relationship between a consumer's attitude and their decision to purchase environmentally friendly products. In addition, Tan, Ojo and Tgurasamy (2019) found that attitude was not a significant predictor of green purchasing behaviour among young consumers, and that attitude was not a significant predictor of green purchasing behaviour among the young consumers. These findings showed an inconsistent link between the impact of attitude on consumers' behaviour, the role of attitude and the green product purchasing behaviour (Biswas and Roy, 2015). This has led to the following hypothesis:

H3: Green purchase decision among youngsters is significantly affected by environmental attitude

\section{Green Advertising}

Environmental advertising, also known as green advertising, is a type of advertising that informs consumers about environmentally friendly products and services offered in order to encourage them to purchase or use environmentally friendly products (Prastiyo, 2016). Among many of the promotional tools, advertising is one of the used forms of indirect communication, based on information about a product's superiority, and organized in such a way that it generates a sense of fun, which will change a person's mind about whether or not to make a purchase (Tjiptono, 2005). Adverts are intended to influence consumers' cognition and evaluation of products and brands as well as their feelings about those products and brands. They also aim to increase consumer knowledge, understanding, meaning, beliefs, attitudes, and images of those products and brands (Peter and Olson, 2000). A study conducted by Delafrooz et al (2014) discovered that environmentally friendly advertising is an action designed to influence consumer attitudes toward purchasing environmentally 
friendly products while also encouraging them to purchase products that is safe to the environment. Green advertising not only has an impact on consumer attitudes toward the environment, but it also contributes to the credibility of claims made in green advertisements, which plays an important role in influencing consumer purchase intentions for environmentally friendly goods and services (Zhu, 2013). Further support for this view comes from research carried out by Ahmad et al (2010), which found that environmental advertising has an impact on consumer purchase intentions for environmentally friendly products. Rahbar and Wahid (2011) discovered that green advertising aids consumers in making purchasing decisions, but that it has no effect on consumer behaviour when it comes to purchasing environmentally friendly products. In order to introduce or explain marketed products, one strategy is to use marketing communication activities such as advertising and promotion activities. Consumers will be willing to pay more for environmentally friendly products, so in order to take advantage of these new opportunities, advertisers must improve their understanding of how consumers respond to environmental advertising claims in their marketing campaigns. The ability to comprehend this will provide advertisers with valuable insights into how to improve the effectiveness of their communications in environmental advertisements (Chan, 2004). When a company uses advertising to communicate with customers, it is doing so in an indirect manner by providing information about the benefits of a product in order to pique the consumer's interest and compel them to purchase the product. This has led to the following hypothesis:

H4: Green purchase decision among youngsters significantly affected green advertising.

Based on the literature, the following framework is developed.

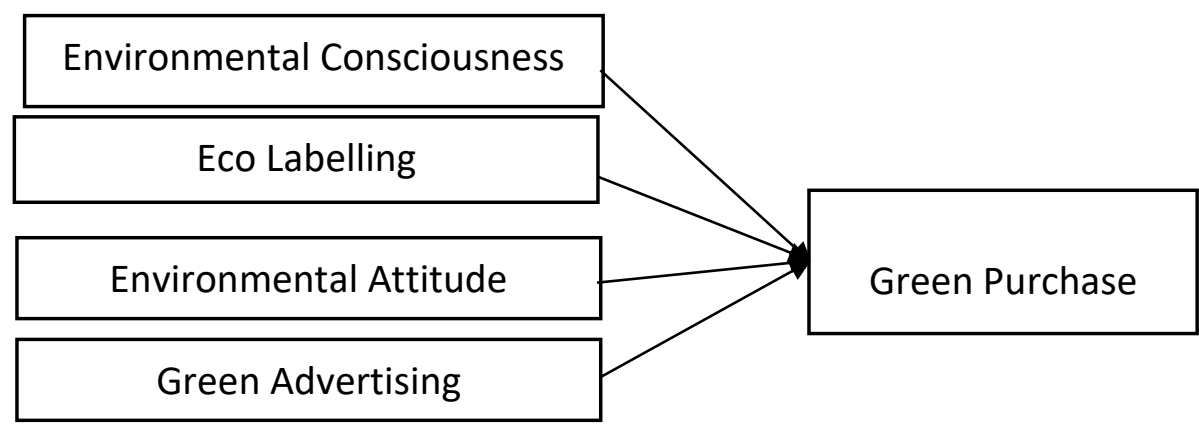

Figure 1: The Proposed Framework

\section{Methodology}

\section{Sample and Data Collection}

This study was conducted online using a quantitative approach of self-reported survey questionnaires that were published on the website. An invitation with an attachment of the hyperlink to the questionnaire website was sent to the respondents using the convenience sampling method. Participation by the respondents was purely voluntary. Overall, 431 responses were obtained. For the data analysis, SPSS 23 and AMOS 23 were used.

From the total of 431 respondents, a total of 326 respondents ( 75.6 per cent) were female while 105 respondents (24.2 per cent) were male. The group age of 18-20 years old (58.2 per cent) and 21-23 years old ( 30.4 per cent) account for the biggest portion of the sample followed by ages of 24-26 years old ( 8.8 per cent) and ages of 27-30 years old (2.3 per cent) respectively. Majority of the respondents (97.7per cent) were single. For education 
accomplishment, about 57.3 percent possessed a diploma qualification, 27.9 percent obtained 38.7 percent a bachelor's degree education

and 4.2 per cent of the respondents hold a high school qualification. Most of the respondents were students and many of the respondents were earning below RM999.00 (85.5 per cent).

Table 1: Respondents' demographic profile ( $\mathrm{N}=431)$

\begin{tabular}{llcc}
\hline \multicolumn{1}{c}{ Respondents' Demographic } & Frequency & \% \\
\hline Gender & Male & 105 & 24.2 \\
\multirow{4}{*}{ Age } & Female & 326 & 75.6 \\
& $18-20$ & 251 & 58.2 \\
& $21-23$ & 131 & 30.4 \\
Marital Status & $24-26$ & 38 & 8.8 \\
& $27-30$ & 11 & 2.3 \\
Level of Education & Married & 10 & 2.3 \\
& Single & 421 & 97.7 \\
& High School & 18 & 4.2 \\
Occupation & Diploma & 248 & 57.3 \\
& Bachelor Degree & 165 & 38.3 \\
& Employed & 40 & 9.3 \\
\multirow{4}{*}{ Monthly Income } & Self-employed & 2 & .5 \\
& Student & 389 & 90.5 \\
& Below RM999.00 & 368 & 85.5 \\
& Between RM1000.00- & 44 & 10.2 \\
& RM2999.00 & & \\
& Above RM3000.00 & 19 & 4.4 \\
\hline
\end{tabular}

\section{Measurement}

The survey questionnaires were adapted from previously related literature with 24 items and were operationalized using 7-point Likert scales, measuring from 1=strongly disagree to $7=$ strongly agree. Factor and reliability analysis were conducted to ensure the validity of the measures. In factor analysis, the construct validity of each category is evaluated using Principal Component Factor Analysis. Varimax rotation method was performed to identify the underlying dimensions of the data. Reliability analysis was used to assess the degree of consistency between multiple measurements of the variables. For data analysis, SPSS 23 was used to assess the model fit and the associated path coefficients between the different variables and AMOS 23 is used primarily for confirmatory factor analysis (CFA) of different variables

\section{Results}

\section{Factor and Reliability Analysis}

All questionnaire items were subjected to factor analysis in order to determine whether or not they were suitable for inclusion in the subsequent multivariate analysis. It is important to note that the results presented are based on sparse sets of variables that have been guided by conceptual and practical considerations. The loadings used are 0.50 and above (Hair et al., 1998), and the cross-loadings are below 0.20 . The principal component analysis (PCA) was used in this study. The communality values for all variables were found to be high, indicating that the total amount of variance that an original variable shares with other 
variables included in the analysis is a significant amount. When examining all 19 items with the constructs of Environmental Concern, Eco Labeling, Environmental Attitude, and Green Advertising using exploratory factor analysis (EFA), the results revealed four factors with factor loadings greater than 0.50 for each of the constructs. Therefore, the validity of the measures was established, confirming that the individual items are measuring the same construct and, as a result, are highly inter-correlated with one another. Kaiser-Meyer-Olkin sampling adequacy is measured at 0.955, and Bartlett's test of sphericity is statistically significant at $(p=0.000)$. Overall, the findings demonstrate that the construct measures are reliable. The instrument's internal consistency was examined through the use of reliability analysis. The construct has a Cronbach's Alpha of 0.85 as shown in Table 2. Hair, Anderson, Thatam, and Black (1998) recommend a lower limit of acceptability of 0.60 , and the results exceed this limit. A high value of discriminant validity, as shown in Table 3, indicates that there are strong relationships between the variables. As a result, the instrumentation demonstrates adequate validity and reliability characteristics.

Table 2: Reliability and Validity of all the Constructs

\begin{tabular}{|c|c|c|c|c|}
\hline Construct & Factor Loading & Cronbach Alpha & CR & AVE \\
\hline Green Advertising & & .944 & .884 & .522 \\
\hline GA4 & .778 & & & \\
\hline GA5 & .747 & & & \\
\hline GA2 & .733 & & & \\
\hline GA3 & .729 & & & \\
\hline EL4 & .697 & & & \\
\hline GA1 & .692 & & & \\
\hline EL5 & .676 & & & \\
\hline Environmental Attitude & & .887 & .821 & .478 \\
\hline ATT2 & .740 & & & \\
\hline ATT4 & .703 & & & \\
\hline ATT5 & .695 & & & \\
\hline ATT1 & .662 & & & \\
\hline ATT3 & .654 & & & \\
\hline Environmental Concern & & .854 & .804 & .516 \\
\hline EC1 & .862 & & & \\
\hline EC2 & .809 & & & \\
\hline EC3 & .619 & & & \\
\hline EC4 & .531 & & & \\
\hline Eco labelling & & .843 & .757 & .510 \\
\hline EL1 & .776 & & & \\
\hline EL2 & .714 & & & \\
\hline EL3 & .647 & & & \\
\hline
\end{tabular}


Table 3: Correlation and Discriminant Validity

\begin{tabular}{lcccccc}
\hline Construct & CR & AVE & GA & EA & EC & EL \\
\hline GA & .884 & .522 & & & & \\
EA & .821 & .478 & $.748^{* *}$ & & & \\
EC & .804 & .516 & $.829 * *$ & $.722^{* *}$ & & \\
EL & .757 & .510 & $.744^{* *}$ & $.694^{* *}$ & $.975^{* *}$ & \\
\hline
\end{tabular}

Note. C.R. = composite reliability; AVE = averaged variances expected ** Correlation is significant at the 0.01 level

\section{Structural Model: Goodness of fit Statistic and Hypothesis Testing}

The goodness of fit was confirmed in the present model using both absolute and incremental fit indices. The proposed model represents a good model fit $\chi 2=513.123$, chi $\chi 2 / d f=2.156$, $\mathrm{GFI}=0.906, \mathrm{TLI}=0.959, \mathrm{CFI}=0.965, \mathrm{RMSEA}=0.052$, suggests that the model satisfactory fits the data (Figure 2). In addition, Table 4 shows the results regarding the postulated hypothesis. Only environmental consciousness ( $\beta=0.12, t=1.619 p<0.1$ ), environmental attitude $(\beta=$ $0.22, t=2.678 p<0.01)$, and green advertising $(B=0.58, t=7.463, p<0.001)$ were significantly related to green purchase decision which supported the hypothesis $H 1, H 3$ and $H 4$ respectively.

Table 4: Analysis Result and Hypotheses Testing

\begin{tabular}{|l|l|c|c|c|c|}
\hline & \multicolumn{1}{|c|}{ Path direction } & $\begin{array}{c}\text { Standardize } \\
\text { d Coefficient } \\
(ß)\end{array}$ & SE & $\begin{array}{c}\text { CR (t } \\
\text { value) }\end{array}$ & Result \\
\hline H1 & $\begin{array}{l}\text { Environmental Consciousness } \\
\text { Green Purchase Behaviour }\end{array}$ & $.12^{*}$ & .069 & 1.619 & Accepted \\
\hline $\mathrm{H} 2$ & $\begin{array}{l}\text { Eco labelling } \rightarrow \text { Green Purchase } \\
\text { Behaviour }\end{array}$ & .07 & .062 & .933 & $\begin{array}{c}\text { Not } \\
\text { Accepted }\end{array}$ \\
\hline $\mathrm{H} 3$ & $\begin{array}{l}\text { Environmental Attitude } \\
\text { Green Purchase Behaviour }\end{array}$ & $.22^{* * *}$ & .073 & 2.678 & Accepted \\
\hline $\mathrm{H} 4$ & $\begin{array}{l}\text { Green Advertising Green } \\
\text { Purchase Behaviour }\end{array}$ & $-58^{* * * *}$ & .075 & 7.463 & Accepted \\
\hline
\end{tabular}

Note $* p<0.1, * * * p<0.01, * * * * p<0.001$ 




Figure 2: Path analysis of structural equation model (SEM)

\section{Finding and Discussion}

The purpose of this study was to empirically assess the young generation's perceived values regarding green purchasing behaviour. The findings substantiated three of the four hypotheses. Environmental consciousness, environmental attitude, and green advertising all have a significant impact on the green purchasing behaviour of the younger generations, corroborating $\mathrm{H} 1, \mathrm{H} 3$ and $\mathrm{H} 4$. This is consistent with previous research, which indicates that when the younger generation demonstrates a strong environmental attitude and consciousness, they exhibit remarkable responses to environmental behaviour. Additionally, the motivation behind this behaviour is backed up by the attitude established through green advertising as mentioned by Yang et al (2015). Consumers who are more environmentally conscious will have a more favourable attitude toward green advertising. Green advertising is also closely associated with motivation to purchase green products because younger generations are more likely to exhibit the 'in-thing' via social media awareness. They are those who are exposed to everyday lifestyle advertisements. This is consistent with Herman, Udayana, and Farida's (2020) findings that green advertising is the most significant potential issue influencing young consumers in Indonesia to choose and use green products. Although the previous research has attempted to demonstrate that green purchasing behaviour is largely determined by the presence of eco labels on products (Perrini et al., 2010), the finding in this research suggests that eco labelling does not necessarily trigger concerns of young generations to purchase green products. These findings raise concerns about the perceived inferiority of eco labelling in explaining the actual buying behaviour of young generations. 
One possible explanation for this is that a strong positive attitude toward green purchasing may have diminished the importance of eco labelling. In short, it is irrelevant whether a product bears an eco-label; what matters is their commitment to purchasing green products. This is further supported by the proliferation of imprecise and perplexing claims which have also appears to have weakened the role of eco-labels in promoting consumers' green intentions as stated in Testa et al (2015).Ecolabels do indeed provide environmental credentials that enable customers to make more informed purchasing decisions, but there is a possibility of an overload of information on ecolabels, or a lack of it, which may have hindered young Malaysians' motivations to purchase based on green labels.

\section{Conclusion}

In conclusion, environmentally responsible business practices are critical. As long as environmental ideology reigns supreme, the green market will thrive. In addition, green business organizations must place a premium on younger generations' demand and satisfaction in order to survive in the long run. This is because the young generations play a major role in the economic contribution. Therefore, the findings from our studies may be adopted by green businesses organizations to promote strategies based on various young generations' motivations to purchase environmentally friendly products.

\section{References}

Ahmad, H., Ahmad, K., \& Shah, I. A. (2010). Factors in environmental advertising influencing consumer's. European Journal of Scientific Research, 48, 217-226.

Alwitt, L. F., \& Pitts, R. E. (1996). Predicting purchase intentions for an environmentally sensitive product. Journal of consumer psychology, 5(1), 49-64.

Auliandri, T. A., Thoyib, A., Rohman, F., \& Rofiq, A. (2018). Does green packaging matter as a business strategy.Exploring young consumers' consumption in an emerging market. Problems and Perspectives in Management, 16(2), 376-384.

Awad, T. A. (2011). Environmental segmentation alternatives: Buyers profile and implications. Journal of Islamic Marketing, 2 (1), 55- 73.

Biswas, A., \& Roy, M. (2015). Green products: An exploratory study on the consumer behaviour in emerging economies of the east. Journal of Cleaner Production, 87, 463468.

Chai, L. T., Lung, C. K., \& Ramly, Z. (2009). Exploring ethical orientation of future business leaders in Malaysia. International Review of Business Research Papers, 5(0), 109-120.

Chan, R. Y. K. (2004). Consumer responses to environmental advertising in China. Marketing Intelligence \& Planning, 22 (4), 427 - 437.

Connell, K.Y.H. (2010). Internal and external barriers to eco-conscious apparel acquisition. International Journal of Consumer Studies, 34 (3), 279-286.

Delafrooz, N., Taleghani, M., \& Nouri, B. (2014). Effect of green marketing on consumer purchase behavior. QScience Connect, 5, 1-9.

Dilotsotlhe, N. (2021). Factors influencing the green purchase behaviour of millennials: An emerging country perspective. Cogent Business \& Management, 8(1), 1908745. DOI: 10.1080/23311975.2021.1908745

Ergen, A., Baykan, B. G., \& Turan, S. G. (2015). Effect of materialism and environmental knowledge on environmental consciousness among high school students: A study conducted in Istanbul province. Journal of Human Sciences, 12(1), 511-526.

http://dx.doi.org/10.14687/ijhs.v12i1.3130 
Eze, U. C., \& Ndubisi, N. O. (2013). Green buyer behavior: Evidence from Asia consumers. Journal of Asian and African Studies, 48 (4), 413-425.

Gallastegui, I. G. (2002). The use of eco-labels: A review of the literature Eur. Environ.1231631. Retrieved from https://onlinelibrary.wiley.com/doi/pdf/10.1002/eet.304.

Global Ecolabelling Network. (2020). Retrieved from https://globalecolabelling.net/what-iseco-labelling/.

Goh, Y. N., \& Wahid, N. A. (2015). A review on green purchase behaviour trend of Malaysian consumers. Asian Social Science, 11(2), 103.

Gupta, S., Ogden, D. T. (2009). To buy or not to buy? A social dilemma perspective on group buying. Journal of Consumer Marketing, 26 (6).

Hair, J. G., Anderson, R. E., Tatham, R. L., \& Black, W. C. (1998). Multivariate analysis. New Jersey: Prentice Hall Inc.

Herman, L. E., Udayana, I. B. N., \& Farida, N. (2021). Young generation and environmental friendly awareness: Does it the impact of green advertising?. Business: Theory and Practice, 22(1), 159-166. https://doi.org/10.3846/btp.2021.12417

Himmelfarb, S. (1993). The measurement of attitudes. The psychology of attitudes, 23-87.

Hsu, C. L., Chang, C. Y., \& Yansritakul, C. (2017). Exploring purchase intention of green skincare products using the theory of planned behavior: Testing the moderating effects of country of origin and price sensitivity. Journal of Retailing and Consumer Services, 34(1), 145-152. https://doi.org/10.1016/j.jretconser.2016. 10.006

Hume, M. (2010). Compassion without action: Examining the young consumers consumption and attitude to sustainable consumption. Journal of world business, 45(4), 385-394.

Joshi, Y., \& Rahman, Z. (2015). Factors affecting green purchase behaviour and future research directions. International Strategic Management Review, 3, 128-143. https://doi.org/10.1016/j.ism.2015.04.001

Kim, Y., \& Choi, S. M. (2005). Antecedents of green purchase behavior: An examination of collectivism, environmental concern, and PCE. ACR North American Advances, 32, 592 $-599$.

Kim, Y. H., \& Chung, J. E. (2011). Consumer purchase intention for organic personal care products. Journal of Consumer Marketing, 28 (1), $40-47$.

Laroche, M., Bergeron, J., \& Barbaro-Forleo, G. (2001). Targeting consumers who are willing to pay more for environmentally friendly products. Journal of Consumer Marketing, 18 (6), $503-20$.

Law, M. M. S., Hills, P., \& Hau, B. C. H. (2017). Engaging employees in sustainable development-a case study of environmental education and awareness training in Hong Kong. Business Strategy and the Environment, 26(1), 84-97.

Lee, K., (2008). Opportunities for green marketing: Young consumers. Marketing Intelligence \& Planning, 26(6), 573-586.

Lin, S. T., \& Niu, H. J. (2018). Green consumption: Environmental knowledge, environmental consciousness, social norms, and purchasing behavior. Business Strategy and the Environment, 27(8), 1679-1688.

Longhurst, A. (2006). The sustainability myth. Fisheries Research, 81(2-3), 107-112.

Maniatis, P. (2016), Investigating factors influencing consumer decision-making while choosing green products. Journal of Cleaner Production, 132, 215-228.

Mansaray, A., \& Abijoye, J. O. (1998). Environmental knowledge, attitudes and behavior in Dutch secondary school. Journal of Environmental Education, 30(2), 4-11. 
McCarty, J. A., \& Shrum, L. J. (2001). The influence of individualism, collectivism, and locus of control on environmental beliefs and behavior. Journal of Public Policy \& Marketing, 20(1), 93-104.

Menon, A., \& Menon, A. (1997). Entrepreneurial marketing strategy: The emergence of corporate environmentalism as a marketing strategy. Journal of Marketing, 61 (1), 51 67.

Meredith, G. E., Schewe, C. D., \& Karlovich, J. (2002). Defining markets, defining moments: America's 7 generational cohorts, their shared experiences, and why businesses should care. Wiley.

Milfont, T. L., \& Duckitt, J. (2010). The environmental attitudes inventory: A valid and reliable measure to assess the structure of environmental attitudes. Journal of Environmental Psychology, 30(1), 80-94. doi:10.1016/j.jenvp.2009.09.001

Moh, Y. C., \& Abd Manaf, L. (2014). Overview of household solid waste recycling policy status and challenges in Malaysia. Resources, Conservation and Recycling, 82, 50-61. ISSN 0921-3449, https://doi.org/10.1016/j.resconrec.2013.11.004.

National eco labelling scheme. (2015). KeTTHA.

Ong, Z., Lau, J., \& Zainudin, N. (2021). Money attitude, materialism and compulsive buying among Malaysian young adults. Management Science Letters, 11(1), 281-290.

Ostfeld, R., Howarth, D., Reiner, D., \& Krasny, P. (2019). Peeling back the label-exploring sustainable palm oil ecolabelling and consumption in the United Kingdom. Environmental Research Letters, 14(1), 014001.

Peattie, K., \& Charter, M. (2003). Green marketing. In Baker, M. J (Eds.), The Marketing Book (pp. 726-755). Great Britain, UK: Butterworth-Heineman

Perrini, F., Castaldo, S., Misani, N., Tencati, A. (2010). The impact of corporate social responsibility associations on trust in organic products marketed by mainstream retailers: a study of Italian consumers. Business Strategy and the Environment, 19, 512526

Peschel, A. O., Orquin, J. L., \& Loose, S. M. (2019). Increasing consumers' attention capture and food choice through bottom-up effects. Appetite, 132, 1-7.

Peter, J. P., \& Olson, J. C. (2000). Consumer behaviour: Perilaku konsumen dan strategi pemasaran, Jilid 1 dan Jilid 2. Jakarta: Erlangga.

Prastiyo, Y. (2016). Pengaruh green marketing tools terhadap perilaku pembelian konsumen. E-Jurnal Manajemen Unud, 5 (6), 3449- 3475.

Rahbar, E., \& Wahid, N. A. (2011). Investigation of green marketing tools' effect on consumers' purchase behavior. Business Strategy Series, 12 (2),73-83.

Rahmayanti, H., Ichsan, I. Z., Oktaviani, V., Syani,Y., Hadi, W., \& Marhento, G. (2020). Environmental attitude for smart city technology: Need assessment to develop smart trash in environmental education. International Journal of Advanced Science and Technology, 29 (3), 8374 - 8383.

Rivera-Camino, J. (2007). Re-evaluating green marketing strategy: a stakeholder perspective. European Journal of marketing, 41 (11/12), 1328 -1343.

Schultz, P. W., Shriver, C., Tabanico, J. J., \& Khazian, A. M. (2004). Implicit connections with nature. Journal of Environmental Psychology, 24, 31-42.

Stern, P. C. (2000). Toward a coherent theory of environmentally significant behaviour. Journal of Social Issues, 56 (3), 407-424.

Tan, C., Ojo, A., \& Thurasamy, R. (2019). Determinants of green product buying decision among young consumers in Malaysia. Young Consumers, 20 (2). 
Taufique, K. M. R., Polonsky, M. J., Vocino, A., \& Siwar, C. (2019). Measuring consumer understanding and perception of eco-labelling: Item selection and scale validation. International Journal of Consumer Studies, 43(3), 298-314.

Testa, F., Iraldo, F., Vaccari, A., \& Ferrari, E. (2015). Why eco-labels can be effective marketing tools: Evidence from a study on Italian consumers [J]. Business Strategy and the Environment, 24, 252-265. https://doi. org/10.1002/bse.1821

Tikka, P. M., Kuitunen, M. T., \& Tynys, S. M. (2000). Effects of educational background on students' attitudes, activity levels, and knowledge concerning the environment. The journal of environmental education, 31(3), 12-19.

Ting, H., Lim, T. Y., de Run, E. C., Koh, H., \& Sahdan, M. (2018). Are we Baby Boomers, Gen X and Gen Y? A qualitative inquiry into generation cohorts in Malaysia. Kasetsart Journal of Social Sciences, 39(1), 109-115. https://doi.org/10.1016/j.kjss.2017.06.004.

Tjiptono, F. (2005). Pemasaran Jasa. Malang: Bayumedia Publishing.

Topic, M., \& Mitchell, B. (2019) Generation Z \& Consumer Trends In Environmental Packaging. Project Report. The Retail Institute, Leeds

Umweltbundesamt. (2018). Blue angel-the german ecolabel: 40 years. good for me. good for the environment.

Wei, S., Ang, T., \& Jancenelle, V. E. (2018). Willingness to pay more for green products: The interplay of consumer characteristics and customer participation. Journal of Retailing and Consumer Services, 45, 230-238.

Yang, D., Lu, Y., Zhu, W., \& Su, C. (2015). Going green: How different advertising appeals impact green consumption behavior. Journal of Business Research, 68(12), 2663-2675. https://doi.org/10.1016/j.jbusres.2015.04.004

Zhai, X., \& An, Y. (2020). Analyzing influencing factors of green transformation in China's manufacturing industry under environmental regulation: A structural equation model. Journal of Cleaner Production, 251, 119760.

Zhou, Y., Selvam, A., \& Wong, J. W. (2014). Evaluation of humic substances during cocomposting of food waste, sawdust and Chinese medicinal herbal residues. Bioresource Technology, 168(9), 229-234. https://doi.org/10.1016/j.biortech.2014.05.070

Zhu, B. (2013). The impact of green advertising on consumer purchase intention of green products world. Review of Business Research, 3 (3), 72 - 80. 